Vol. 2, No. 2, December 2021

\title{
SPEKTA
}

Jurnal Pengabdian Kepada Masyarakat : Teknologi dan Aplikasi

Journal homepage :

http://journal2.uad.ac.id/index.php/spekta

\section{THE UTILIZATION OF NON-ORGANIC WASTE TOWARDS KAMPUNG SAYUR TO EMPOWER THE WASTE BANK IN KAMULYAN}

\section{Isana Arum Primasari *, Hayati Mukti Asih}

Department of Industrial Engineering, Universitas Ahmad Dahlan, Indonesia

\section{ARTICLE INFO \\ Received : January, 2021 \\ Revised : September, 2021 \\ Accepted : September, 2021}

Keywords:

waste;

kampung sayur;

vertical garden.

\begin{abstract}
Waste is a problem in environment and society that has never been resolved. One of the triggers for waste is the use of disposable product packaging. Reducing singleuse waste by reusing it will impact reducing waste generation so that the city becomes clean. Reuse of waste by making it the basic material for an innovative product will add value to waste to no longer pollute the environment. The existence of the Kampung Sayur program in Brontokusuman has made waste no longer underestimated. The location of Brontokusuman in the middle of a densely populated city is an obstacle in implementing "the vegetable village" program so that the need for community empowerment in managing waste wisely. The community empowerment program implemented in Brontokusuman aims to provide education to the community in managing waste. organic and non-organic wisely.Therefore, the training of vertical garden was conducted to support that program.
\end{abstract}

\section{INTRODUCTION}

Waste becomes a problem in communities that never meet its ends as it requires awareness and involvement from multiple parties. The waste becomes the root of all environmental problems so that by solving the garbage problem, it will solve other environmental problems at the same time (Akil et al., 2015; Miezah et al., 2015; Warmadewanthi \& Kurniawati, 2018). The use of single-use product packaging is one of the triggers for waste. Therefore, reducing single-use waste with a reuse program will greatly influence waste products. It will directly impact the clean-based environment in cities. According to Sulastri, the Daily Executive of the Indonesian Consumers Foundation (YLKI), the upstream part of the garbage product including the use of singleuse packaging products needs to be addressed as the plastic waste puzzle will never be solved if the upstream is not monitored (https://fin.co.id/2020) However, the reuse of

\footnotetext{
* Corresponding author.

E-mail address: isana_prisa@ie.uad.ac.id

https://doi.org/10.12928/J.spekta.v2i2.3355
} 
waste by allocating it into the basic material of an innovative product will add a new value. It will no longer pollute the environment.

The "Kampung Sayur" or known as the Vegetable Village program is planned to be implemented in Brontokusuman Village, Mergangsan District, Yogyakarta. It is a great plan for reforestation and food self-sufficiency for the local community. This program has been initiated in 2019 and carried out simultaneously by all Brontokusuman residents (https://brontokusumankel.jogjakota.go.id/). The existence of the Kampung Sayur program in Brontokusuman Village changes the existence of waste that has previously been underestimated. This also becomes a priority program for the local community neighborhood (Rukun Warga) of 20-22. Most of those are members of the Kamulyan waste bank chapter. Some activities carried out by the Kamulyan waste bank chapter include collecting used goods, weighing non-organic waste, and saving from the sale of waste. Unfortunately, the local community is still lack of knowledge about how to process organic and non-organic waste.

The strategic location of Brontokusuman, which is in the middle of the densely populated city of Jogjakarta, is an obstacle in implementing the vegetable village program. The setting of the houses that are close to each other causes no longer houses has land to grow vegetables. This needs to be the attention of various parties to provide solutions so that Brontokusuman residents are able to carry out the Kampung Sayur program as a manifestation of the spirit of greening the city of Jogjakarta. Several similar programs were also implemented by raising the object of empowering organic villages in Mojosongo, Jebres, Surakarta (Ramayana, 2021; (Budiyanto et al., 2020)). Besides, there are also mushroom villages in Koto Tangah Padang District (Putri, 2018; (Andriastuti et al., 2019; Ariyani et al., 2021; Chandra, 2020)), and Organic Vegetable Villages in Ngemplak Sutan Mojosongo Jebres (Rahman, 2017; (Fitriani \& Asih, 2019)). The Community Empowerment Program through the Vegetable Village program was the first to be carried out in Brontokusuman Village.

The community empowerment program implemented in Brontokusuman aims to provide education to the community in managing organic and non-organic waste wisely. One of the activities carried out was training on making Vertical Gardens as a green solution in a narrow urban area. It is to support the Vegetable Village program in Brontokusuman Village.

The benefits of the Vertical Garden include reducing non-organic waste, saving planting land, saving water and media, increasing production, environmental sanitation, organic farming, and urban agriculture. The utilization of goods that are not used is reprocessed into products that have value and benefits carried out in this program. This program is in accordance with the PPM strategic plan launched by LPPM UAD, which is related to achievements in "Acceleration of marginal areas towards environmentally friendly areas with socio-ecopreneur character, universal and Islamic values" (Widodo, 2020).

The training on making Vertical Gardens is very cost-effective as all the materials used are from non-organic waste and other materials that are readily available at home. Some of the materials and tools used are:

1. Materials: used bottles, used cans, used jars, rope or wire, stoppers

2. Tools: cutter, scissors, plywood saw, pliers

3. Steps of manufacture:

a. Clean the plastic bottles from the rest of the drink liquid and labels 
Vol. 2, No. 2, December 2021

b. Make holes in the bottle body according to the needs of the plant planting medium, usually a quarter of the bottle lengthwise.

c. Bottle-mouth saw for rope or wire placement

d. Insert the connecting rope between the bottles into the mouth of the bottle that has been sawed and then close the lid tightly in order not to come off easily.

e. Tie the bottom of the bottle with a rope and then secure it using a stopper

f. Do the same for the next bottle

g. Connect all bottles vertically until all bottles are assembled together

h. The vertical garden is ready to be installed as a house fence

\section{METHOD}

The method of community service implementing process included counseling, training, and knowledge transfer activities. In specific, the purpose of this community service was to increase the knowledge and skills of the residents in processing nonorganic waste to support the "Kampung Sayur" program. The residents around the Kamulyan Waste Bank were invited to utilize non-organic waste into more useful products for their daily life. This program was started by educating the process and use of waste and its benefits for the environment. Non-organic waste can be reduced by reusing it into products that are more useful and are more valuable.

Furthermore, training programs and practices for creating pot media using used materials were also carried out at the same time. This was to change the appearance of used pots into beautiful pots. It's also hoped that the "Kampung Sayur" program would be more beautiful on limited land with the Vertical Garden. A vertical garden was built on an upright or vertical plane, usually, this garden was made on a narrow and limited land inside the house or outside the house so that it can also use the wall to grow plants. The vertical garden is one of the gardening concepts holding the motto of "Go Green" as the manufacture of vertical gardens is generally often carried out using recycled materials. Used bottles made of glass or plastic are often used because they are easy to obtain and cheap in price as well as being able to reduce the generation of non-organic waste. Therefore, the Vertical garden became one of the efforts to reduce waste in urban communities. The particular method in this community service is as figured out through the following Figure 1.

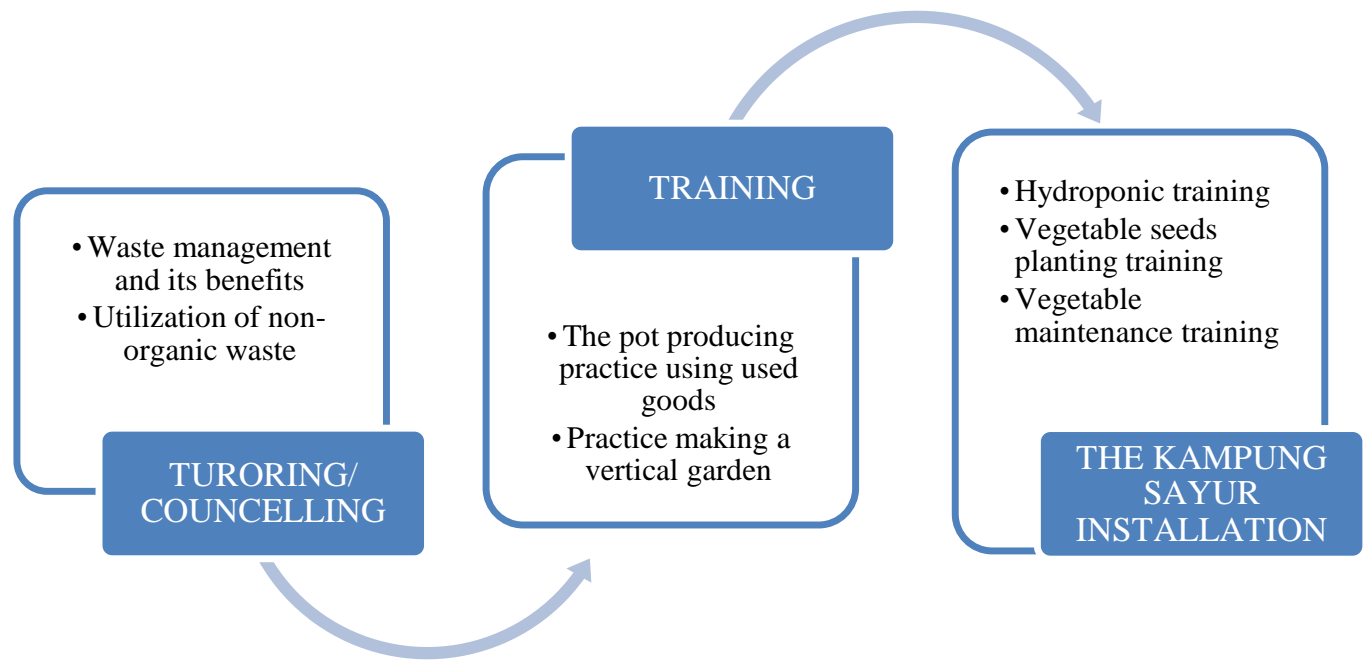

Figure 1. The empowerment method of Kampung Sayur 
Vol. 2, No. 2, December 2021

A series of community service activities carried out during June - November 2020 are detailed as the following lists:

1. Counseling on the reduction of non-organic waste. Most of the local community knew and understood the benefits of non-organic waste. However, there are only some who did it.

2. Mapping suitable locations for vertical garden plants. Not every place and alley is suitable and possibly applied for vertical gardens. It needs a strategic location mapping to make it easier to maintain.

3. Improving the skills of the local community for the use of various nonorganic wastes, especially glass and plastic bottles. This non-organic waste can be used as a vegetable pot which can be used as a medium for vertical garden gardens in houses around the Kamulyan Waste Bank.

\section{RESULTS AND DISCUSSION}

A series of community service activities that have been conducted in Brontokusuman Village as previously described have succeeded in increasing the knowledge of the local community in terms of:

1. Counseling on the benefits of reducing non-organic waste. Most of the local community has generally heard the benefits of non-organic waste. However, not all residents know how to do it. According to the assigned questionnaires given to the trained participants, there were 6 out of 23 participants who have good understanding of the process of waste reduction independently. It indicates that there was an increase in knowledge of $74 \%$.

2. Mapping suitable locations for vertical garden plants. Not every place and alley is suitable for the vertical garden. It needs a strategic location mapping to make it easier to maintain.

3. Improving the local community's skill on the use of various non-organic wastes, especially glass bottles and plastic bottles. This non-organic waste can be utilized as a vegetable pot for vertical gardens in the houses around the Kamulyan Waste Bank. All training participants made pots from plastic bottles to become vertical gardens and glued and installed them in their homes. Figure 2 and Figure 3 show documentation of vertical garden creation activities.

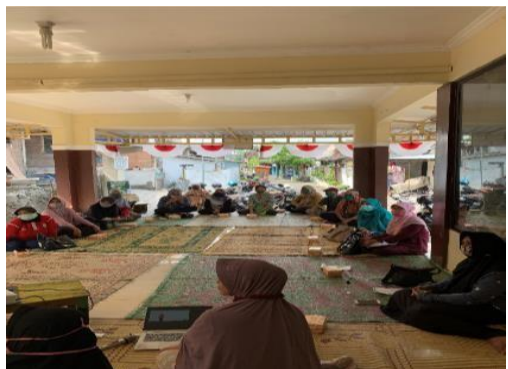

(a). Counseling on the use of nonorganic waste

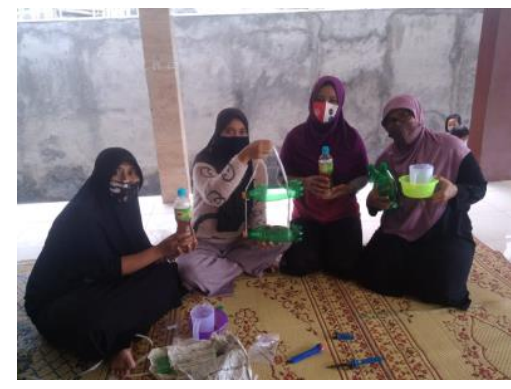

(b). Non-organic Waste Utilization Training 
Vol. 2, No. 2, December 2021



(c). The completion of vertical garden training (Group 1)

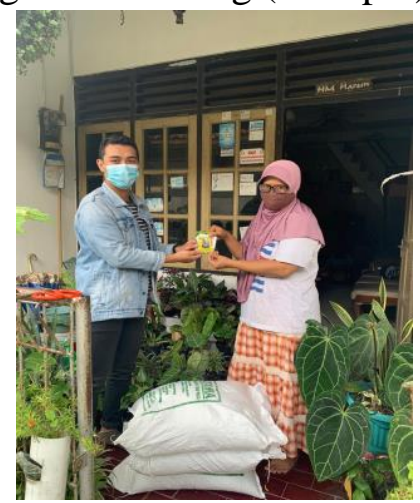

(e). The hand-over of training material

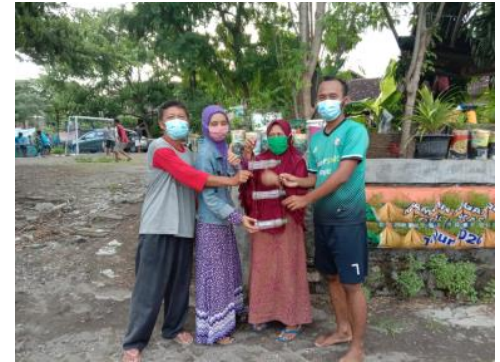

(d). The completion of vertical garden training (Group 2)

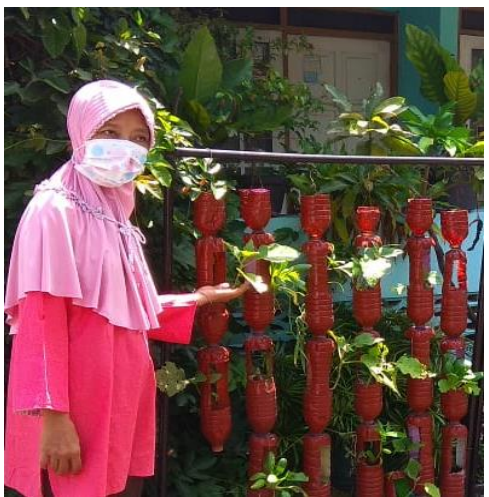

(f). The vertical garden becomes a fence

Figure 2. The programs documentations

It is hoped that this program will be periodically conducted. It is not only considered as an environmental concern but also from a social and economic perspective. In terms of the environment, the creation of this vertical garden can certainly reduce organic and non-organic waste that has not been used properly. For the social side, this activity is carried out in mutual cooperation among the local community around the Kamulyan Waste Bank which can strengthen the relationship. Then, from an economic point of view, the manufacture of this vertical garden can also be sold to increase the welfare of the community. Furtherly, the sustainability of the environmental, social, and economic aspects of the vertical garden program can be seen in Figure 3.

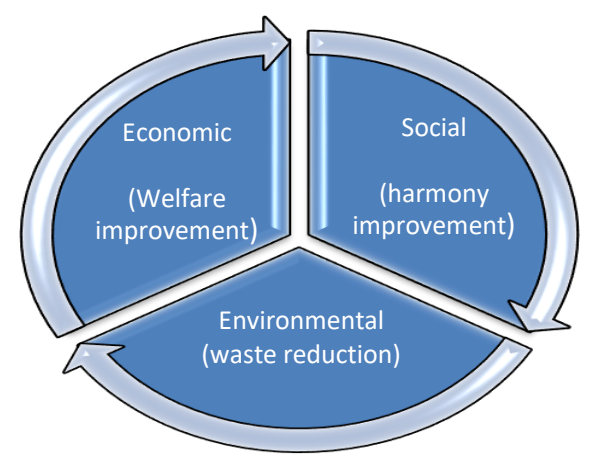

Figure 3. Sustainability between environmental, social, and economic aspects in the vertical garden program 
Vol. 2, No. 2, December 2021

\section{CONCLUSION}

The community service programs at the Kamulyan Waste Bank have been carried out through counseling on the use of non-organic waste and training in installing the vertical gardens. This program is aimed to support the Brontokusuman Village program, Kampung Sayur on the narrow or thin space around the houses. The counseling and training provided to residents have succeeded in increasing knowledge in the use of nonorganic waste to be reprocessed into various products that are beneficial and valuable. Besides, the training on installing vertical gardens from used bottles and various other used items becomes a medium to grow vegetables they have limited and narrow space. However, as the local community is highly motivated, this activity was also considered very helpful to reduce the amount of waste wasted around the environment. The results of the education and training that have been carried out at the Kamulyan Waste Bank to support the "Kampung Sayur" program in the Brontokusuman Village are in line with the circumstances of the community. It is considered very economical as it does not require high costs to prepare.

\section{ACKNOWLEDGEMENT}

The authors would like to express their gratitude to various parties for all the supports so that this community service program could be smoothly carried out. We would like to deliver our deep gratitude to various parties as follows: 1) Universitas Ahmad Dahlan Yogyakarta under the Institute for Research and Community Service for the opportunity given to the community service program. Besides, the authors also would like to express their gratitude for affording grants for activities so that this program could smoothly be done; 2) Kamulyan Garbage Bank segment through the head of the community, Mrs. Utik for the opportunity and time to support this community service; 3 ) Local community around the Kamulyan Waste Bank who actively participate in the activities and practice during this community service.

\section{REFERENCES}

Akil, A. M., Foziah, J., \& Ho, C. S. (2015). The Effects of Socio-Economic Influences on Households Recycling Behaviour in Iskandar Malaysia. Procedia - Social and Behavioral Sciences, 202(December 2014), 124-134.

Andriastuti, B. T., Arifin, \& Fitria, L. (2019). Potensi Ecobrick dalam mengurangi sampah plastik rumah tangga di kecamatan pontianak barat. Teknologi Lingkungan Lahan Basah, 07(2), 55-63.

Ariyani, D., Warastuti, N., \& Arini, R. (2021). Ecobrick Method To Reduce Plastic Waste In Tanjung Mekar Village, Karawang Regency. Civil and Environmental Science, 004(01), 022-029.

Biopori Adalah : Manfaat, Cara Membuat dan Perawatannya, 2020, https://adalah.co.id/biopori/ diakses tanggal 14 oktober 2020

Budiyanto, T., Astuti, R. D., \& Purwani, A. (2020). Pelatihan Dan Pendampingan Pengolahan Sampah Menjadi Produk Bernilai Ekonomi Pada Bank Sampah Bersih Bersama Karanganom, Sitimulyo, Piyungan, Bantul. SPEKTA (Jurnal Pengabdian Kepada Masyarakat : Teknologi Dan Aplikasi), 1(2), 49.

Chandra, W. (2020). Ecobrick, Solusi Atasi Sampah Plastik selama Pandemi COVID-19. Mongabay, April. https://www.mongabay.co.id/2020/04/18/ecobrick-solusi-atasisampah-plastik-selama-pandemi-covid-19/ 
Vol. 2, No. 2, December 2021

Fitriani, S., \& Asih, H. M. (2019). Metode Full Costing Sebagai Dasar Penentuan Harga Produk Kreasi Sampah Ecobrick. Jurnal Integrasi Sistem Industri, 6(1), 65-69. http://jurnal.umj.ac.id/index.php/jisi0Ayang

Lili Dasa Putri, 2018, Kampung Jamur Sebagai Bentuk Pemberdayaan Masyarakat Di Cikarau Kelurahan Dadok Tunggul Hitam Kecamatan Koto Tangah Kota Padang, Jurnal COMM-EDU, Volume 3 Nomor 2, Mei 2020, ISSN : 2622-5492 (Print) 26151480

Lorong sayur Brontokusuman, 2019, https://brontokusumankel.jogjakota.go.id/ diakses tanggal 14 oktober 2020

Manfaat biopori bagi lingkungan, https://manfaat.co.id/manfaat-lubang-biopori diakses tanggal 14 oktober 2020

Miezah, K., Obiri-Danso, K., Kádár, Z., Fei-Baffoe, B., \& Mensah, M. Y. (2015). Municipal solid waste characterization and quantification as a measure towards effective waste management in Ghana. Waste Management, 46, 15-27.

Peluncuran Produk Air Minum Kemasan Galon Sekali Pakai Disesalkan, 2020, https://fin.co.id/2020/05/10/peluncuran-produk-air-minum-kemasan-galon-sekalipakai-disesalkan/ diakses tanggal 14 oktober 2020

Ramajaya. M, Retnowat. D, Kismantoroadji. T, (2021), Pemberdayaan Masyarakat Melalui Program Kampung Organik (Studi Kasus Di Kampung Ngemplak Sutan Kelurahan Mojosongo Kecamatan Jebres Kota Surakarta), jurnal Dinamika Sosial Eknonomi, 22, 23-35.

TPST kelebihan kapasitas terus, 2020, https://tirto.id/masalah-sampah-di-jogja-tpstkelebihan- kapasitas-terus-dipaksakan-eyjX diakses tanggal 14 oktober 2020

Tri Abdul Rahman, Sutarto, Agung Wibowo, 2017, Pengembangan Kampung Sayur Organik Di Ngemplak Sutan, Mojosongo, Jebres, Surakarta, SEPA : Vol. 14 No.1 September $2017: 8-17$, ISSN : 1829-9946.

Tuntaskan masalah sampai dari huku samapai hilir, 2020, https://www.balipost.com/news/2020/12/24/165144/Tuntaskan-Masalah-Sampahdari-Hulu...html, diakses tanggal 25 Desember 2020

Warmadewanthi, I. D. A. A., \& Kurniawati, S. (2018). The potential of household solid waste reduction in Sukomanunggal District, Surabaya. IOP Conference Series: Earth and Environmental Science, 106(1).

Widodo, 2020, Rencana Strategis Pengabdian Kepada Masyarakat Universitas Ahmad Dahlan Tahun 2020-2024, Lembaga Penelitian dan Pengabdian Masyarakat Universitas Ahmad Dahlan 
SPEKTA

Jurnal Pengabdian Kepada Masyarakat : Teknologi dan Aplikasi

Vol. 2, No. 2, December 2021

This page is intentionally left blank. 